\title{
Stable isotopes as a method for analysis of the contribution of different dietary sources in the production of Macrobrachium amazonicum
}

\author{
Ademir Heldt ${ }^{1}$, Sabrina Suita ${ }^{3}$, Fabrício Martins Dutra ${ }^{1}$ \\ Alexandre Leandro Pereira ${ }^{2}$ \& Eduardo Ballester ${ }^{1}$ \\ ${ }^{1}$ Laboratory of Prawn Farming, Postgraduate Program in Aquaculture and Sustainable Development \\ Federal University of Paraná, Palotina, Brazil \\ ${ }^{2}$ Adjunct Professor, Federal University of Paraná, Palotina, Brazil \\ ${ }^{3}$ Marine Aquaculture Station, Federal University of Rio Grande, Rio Grande, Brazil \\ Corresponding author: Eduardo Ballester (elcballester@yahoo.com.br)
}

\begin{abstract}
Macrobrachium amazonicum is the native freshwater prawn species with the greatest potential for captive production in Brazil. The stable isotope carbon and nitrogen technique $\left(\delta^{13} \mathrm{C}\right.$ and $\left.\delta^{15} \mathrm{~N}\right)$ is efficient to determine the contribution of different food sources to a given organism. We used this technique to estimate the contribution of the food sources in the biomass gain of M. amazonicum. Fish fillets were used to determine the isotopic fractionation between juveniles of $M$. amazonicum and a standard food source. Juvenile M. amazonicum were submitted to four treatments with different food availability to determine their contributions; T1: without soil substrate and with feed supply; T2: without soil substrate and feed supply; T3: with soil substrate, feed supply and addition of an aquatic macrophyte (Elodea sp.); and, T4: with soil substrate, aquatic macrophytes and without feed supply. Periphyton, plankton and precipitated organic material were present in all treatments. The isotopic fractionation was $0.57 \pm 0.07$ (carbon) and $2.14 \pm 0.18$ (nitrogen). The prawn fed with ration presented growth 2.4 and 2.82 times higher in the treatments without substrate (T1) and with substrate and macrophytes (T3), respectively. The contribution of the food sources reinforces omnivore in prawn. The benthic organisms and feed supply were fundamental for the better growth performance of M. amazonicum. Estimating the effective contributions of food sources can help in developing diets more adequate for the species, increasing productivity, reducing costs and reducing the environmental impact of waste substances.
\end{abstract}

Keywords: Amazon river prawn; isotopes fractionation; nutritional composition; aquaculture

\section{INTRODUCTION}

The precepts of sustainable aquaculture involve the use of areas with integrated cropping systems and investment in the production of species in regions far from the coast, reducing pressure on fragile environments such as estuaries and mangroves (Valenti, 2007). By complying with such precepts, investment in freshwater prawn farming has been regaining its growth, with an increase in production over the last decade of about $25 \%$ and over $1,000 \%$ if we consider the last 20 years (FAO, 2016).

In Brazil, the only species of freshwater prawn commercially produced in captivity is the exotic species Macrobrachium rosenbergii (De Man, 1879). However, the native species Macrobrachium amazonicum
(Heller, 1862), Macrobrachium acanthurus (Weigmann, 1836), and Macrobrachium carcinus (Linnaeus, 1758), are exploited by fisheries mainly in the north and northeast regions of Brazil (Valenti, 2007; Maciel \& Valenti, 2009) and represent an important source of income for hundreds of artisanal fishermen and their families in these regions. Among those species, $M$. amazonicum shows the greatest potential for captive production (Moraes-Valenti \& Valenti, 2010; Marques $\&$ Moraes-Valenti, 2012). This prawn can reach $16 \mathrm{~cm}$ and $30 \mathrm{~g}$ (Moraes-Valenti \& Valenti, 2010), with a firmer texture and a more pronounced flavor in relation to $M$. rosenbergii meat, which is better accepted by the consumers (New et al., 2010).

Due to the economic and ecological importance of M. amazonicum, studies that provide detailed knowled-

Corresponding editor: Fernando Vega-Villasante 
ge about the species are still necessary to understand its biological and nutritional aspects (Zavala-Camin, 1996). The evaluation of the alimentary spectrum of a given species occurs through the analysis of stomach contents and complementary studies in the environment and on the morphology of the digestive tract for its classification according to the food types and trophic levels (Junger et al., 1988). However, this type of study only points out the ingested items, but not their actual contribution to the biomass gain (Abreu et al., 2007; Suita et al., 2016). For this purpose, the use of stable isotopes of carbon and nitrogen $\left(\delta^{13} \mathrm{C}\right.$ and $\left.\delta^{15} \mathrm{~N}\right)$ might be an efficient tool, as already observed in studies with other crustacean species (Yokoyama et al., 2005; Coman et al., 2006; Cardona et al., 2015; Ballester et al., 2016; Suita et al., 2016).

The different isotope mass numbers of carbon and nitrogen enable their identification and quantification (Groot, 2004). Therefore, they are the most used stable isotopes in ecological and biological research (Moretti et al., 2003). Even when there are many potential food sources, it is possible to determine their probable combinations used and assimilated by a certain consumer organism through statistical/mathematical models (Phillips \& Gregg, 2003; Ballester et al., 2016), provided some assumptions are obeyed. These assumptions include the knowledge of the turnover, which is the time necessary to obtain the equilibrium between the isotopic signal of a diet and the consumer's tissues, variable according to each species and stage of life. A period of 15 days was estimated to be enough to achieve the isotopic balance between diet and body tissues for juvenile shrimp (Gamboa-Delgado \& Le Vay, 2009; Gamboa-Delgado et al., 2013). Cardona et al. (2015) determined that, from 21 days onwards, there was a balance between the isotopic signals of the diet of juvenile Litopenaeus vannamei.

Another premise is the knowledge of isotopic fractionation that occurs due to the accumulation of heavier isotope atoms in the tissues of the consumer organism (Fry, 2006). According to Peterson \& Fry (1987), the isotopic fractionation for aquatic animals varies from 0 to $1 \%$ for carbon and from 0 to $4 \%$ for nitrogen. However, for M. amazonicum, the turnover and isotopic fractionation values are unknown and may raise doubts when estimating the contribution of the different food sources to a better growth performance of the species. Thus, the objective of our study was to find out the turnover, determine the isotopic fractionation between juvenile $M$. amazonicum and their standard diet and estimate the contribution of different dietary sources present in semi-controlled environments for the tissue formation in juveniles.

\section{MATERIALS AND METHODS}

The experiments were carried out in the Laboratory of Prawn Farming of the Federal University of Paraná (UFPR-Palotina Sector), using juveniles from the UNESP Aquaculture Center (CAUNESP-Jaboticabal campus, São Paulo). The present study comprised two experiments; the first aiming to determine a specific fractionation and turnover; and the second, the contribution of different food sources to the growth of M. amazonicum.

The following parameters were monitored daily in both experiments: temperature (Digital Thermometer $\mathrm{CE}^{\circledR}$ ), dissolved oxygen (Oximeter AT-170 Afakit $^{\circledR}$ ), $\mathrm{pH}$ ( $\mathrm{pH}$ meter AT-315 Alfakit $^{\circledR}$ ), and conductivity (AT230 Conductivity Meter). Samples were collected every 10 days (experiment 1 ) and weekly (experiment 2) to quantify the concentrations of ammonia $(\mathrm{N}-\mathrm{AT})$ and nitrite $\left(\mathrm{NO}_{2}{ }^{-}\right)$present in the water of the culture system, according to the methodology proposed by Mackereth et al. (1978). Alkalinity and hardness were evaluated according to Walker (1978), and nitrate $\left(\mathrm{NO}_{3}\right)$ concentrations were determined with a spectrophotometer 2000UV (BE Photonics ${ }^{\circledR}$ ) according to Mackereth et al. (1978). The animals were counted and measured (weight and length) at the start and end of each experiment to determine survival, growth and biomass gain. During experiment 1 , each tank was verified daily for the presence of dead animals, which were removed from the tank to avoid cannibalism.

\section{Experiment 1 - Determination of isotopic fractio- nation}

Juveniles of $M$. amazonicum (initial weight $=0.57 \pm$ $0.09 \mathrm{~g}$; initial length $=3.88 \pm 1.80 \mathrm{~cm}$ ) were maintained at a density of 100 ind $\mathrm{m}^{-2}$ for 30 days in a $300 \mathrm{~L}$ polyethylene tank with the bottom area of $0.5 \mathrm{~m}^{2}$, connected to a biofilter, to determine the isotopic fractionation. Following the recommendations of Yokoyama et al. (2005), the diet of 5.2\% of total prawn biomass (measured in the initial biometry) was composed of a single food source per treatment, therefore $4 \mathrm{~g}$ of tilapia fillets Oreochromis niloticus (dry matter 25\%) was supplied three times per day (08:00, 13:00 and 17:00 h).

Two animals were collected every three days, where the musculature was removed. The muscles were dried, ground, weighed in tin capsules $(5 \times 9 \mathrm{~mm})$ and sent for analysis of the isotopic profile of carbon $\left(\delta^{13} \mathrm{C}\right)$ and nitrogen $\left(\delta^{15} \mathrm{~N}\right)$ in the Isotopic Ecology Laboratory of the CENA/ESALQ-USP (Piracicaba, SP, Brazil). The values of the isotopic ratios of carbon $\left(\delta^{13} \mathrm{C}\right)$ and nitrogen $\left(\delta^{15} \mathrm{~N}\right)(\%)$ were compared with the universal references of PDB (Pee Dee Belemnite) and atmospheric 
nitrogen (Fry, 2003), respectively. This comparison was performed through the equation $\delta(\%)=\left(\mathrm{R}_{\text {sample }}\right.$ $R_{\text {standard }}$ / $R_{\text {sample }} \times 1000$, where " $R$ " is the ratio between the heavy and light isotopes $\left({ }^{13} \mathrm{C} /{ }^{12} \mathrm{C}\right.$ and $\left.{ }^{15} \mathrm{~N} /{ }^{14} \mathrm{~N}\right)$ of sample and standard, respectively. The values from the $21^{\text {st }}$ day onwards were considered for calculating the isotopic fractionation, using the equation: $\Delta(\%)=$ $\delta_{\text {tissue }} \delta_{\text {source }}$ (Cardona et al., 2015).

\section{Experiment 2 - Contribution of food sources}

This experiment lasted 60 days, in which four treatments (T1, T2, T3, and T4) were randomly distributed in four experimental units mounted outdoor Sansuy ${ }^{\circledR}$ tanks with a volume of 5,000 L and a bottom area of 5 $\mathrm{m}^{2}$, with aeration from a radial blower distributed by one large porous stone $(20 \mathrm{~cm})$ per experimental unit.

The prawn (initial weight $=0.30 \pm 0.10 \mathrm{~g}$ and initial length $=3.48 \pm 0.42 \mathrm{~cm}$ ) were stocked at a density of 20 ind $\mathrm{m}^{-2}$. Only two tanks received $20 \mathrm{~cm}$ of soil substrate (T3 and T4), but all of them received chemical fertilization with triple superphosphate $\left(3 \mathrm{~g} \mathrm{~m}^{-2}\right)$ and limestone $\left(200 \mathrm{~g} \mathrm{~m}^{-2}\right)$ (Ostrensky \& Boeger, 1998). The tanks remained filled for 10 days without prawn before the beginning of the experiment, allowing the development of biofilm and planktonic and benthic organisms. The treatments were designed as follows; treatment $1(\mathrm{~T} 1)=$ without soil substrate and with feed supply with $40 \%$ of crude protein and $7.5 \%$ Ethereal Extract (Potimar 40J-Guabi ${ }^{\circledR}$ ); treatment 2 (T2) = without soil substrate and without feed supply; treatment 3 (T3) = with soil substrate, feed supply and the addition of an aquatic macrophyte (Elodea sp.); and, treatment 4 (T4) = with soil substrate, aquatic macrophytes and without feed supply. Biofilms suspended organic material (plankton) and precipitated organic matter was considered as food sources in all treatments.

Five prawns were collected per treatment to analyse the isotopic values of carbon $\left(\delta^{13} \mathrm{C}\right)$ and nitrogen $\left(\delta^{15} \mathrm{~N}\right)$, together with samples of available food sources: plankton (retained by filtration in a quartz filter), biofilm (by scraping PVC plates of $2 \times 10 \mathrm{~cm}$ previously submerged in the tank water), benthic organisms (collected with Petersen dredge) and feed. These samplings were repeated after 20 (Group 1), 40 (Group 2) and 60 (Group 3) days (except for ration).

The feed was offered in two daily meals in the proportion of $40 \%$ of the biomass stocked at the beginning of the experiment during the first 30 days (Cutolo \& Valenti, 2005). After 25 days, this proportion was adjusted to $20 \%$ of the biomass, according to the biometry of individuals collected on the $20^{\text {th }}$ day (Penteado et al., 2013).

\section{Data analysis}

Data on water quality, size, and weight of produced prawn were submitted subjected to the assumptions of normality and homogeneity of the variances (Sokal \& Rolhf, 2012). After those assumptions were confirmed, they underwent submitted to an analysis of variance (ANOVA; $\alpha=0.05$ ). Whether significant differences were verified, the post-hoc Tukey's test was applied.

The Bayesian analysis structure was used to estimate the contribution of each food source to the prawn biomass, with the package Siar-Stable Isotope Analysis in R (Parnell et al., 2010) for intermediate sampling (20 and 40 days) and final sampling (60 days). The analysis correlates carbon (X-axis) and nitrogen (Y-axis), plotting the points in a cartesian plane.

\section{RESULTS}

\section{Experiment 1- Isotopic fractionation}

At the end of the experimental period, the prawns had a mean weight of $0.89 \pm 0.05 \mathrm{~g}$, a total length of $5.09 \pm$ $1.85 \mathrm{~cm}$ and a survival rate of $68 \%$. Water quality variables monitored during the experiment are shown in Table 1.

A variation in the isotopic values of carbon ${ }^{13} \mathrm{C}$ and nitrogen ${ }^{15} \mathrm{~N}$ is observed in prawns fed tilapia fillets. The mean isotopic values for $\delta^{13} \mathrm{C}$ and $\delta^{15} \mathrm{~N}$ were -19.17 \pm 0.07 and $8.28 \pm 0.18$, respectively. The value of the food source (fish fillet) was $\delta^{13} \mathrm{C}=-19.74$ and $\delta^{15} \mathrm{~N}=$ 6.14. The fractionation obtained was $0.57 \pm 0.07$ for ${ }^{13} \mathrm{C}$ carbon and $2.14 \pm 0.18$ for ${ }^{15} \mathrm{~N}$ nitrogen, with a turnover of approximately 15-20 days. The values obtained in this experiment were used to determine the contribution of different dietary sources in experiment 2.

\section{Experiment 2- Contribution of food sources}

The water quality variables differed for conductivity, dissolved oxygen, and hardness. The other variables were similar in all treatments as presented in Table 2.

Table 1. Water quality variables (mean $\pm \mathrm{SD}$ ) monitored during the isotopic fractionation experiment.

\begin{tabular}{lr}
\hline \multicolumn{2}{c}{ Water quality variables } \\
\hline Temperature $\left({ }^{\circ} \mathrm{C}\right)$ & $28.26 \pm 0.65$ \\
pH & $7.65 \pm 0.48$ \\
Dissolved oxygen $\left(\mathrm{mg} \mathrm{L}^{-1}\right)$ & $7.35 \pm 0.34$ \\
Total ammonia $\left(\mathrm{mg} \mathrm{L}^{-1}\right)$ & $0.02 \pm 0.01$ \\
Nitrite $\left(\mathrm{mg} \mathrm{L}^{-1}\right)$ & $0.03 \pm 0.05$ \\
Alkalinity $\left(\mathrm{mg} \mathrm{L}^{-1}\right)$ & $110.76 \pm 9.02$ \\
Hardness $\left(\mathrm{mg} \mathrm{L}^{-1}\right)$ & $28.67 \pm 16.65$ \\
\hline
\end{tabular}


Table 2. Water quality variables (mean $\pm \mathrm{SD}$ ) of the experiment on the different food source contribution to the growth of prawn. Different superscript letters in a row indicate significant difference $(P<0.05)$. Whereas that lines without letters did not show any difference.

\begin{tabular}{lcccc}
\hline \multirow{2}{*}{ Water quality variables } & \multicolumn{4}{c}{ Treatments } \\
\cline { 2 - 5 } \cline { 2 - 5 } & $\mathrm{T} 1$ & $\mathrm{~T} 2$ & $\mathrm{~T} 3$ & $\mathrm{~T} 4$ \\
\hline Temperature $\left({ }^{\circ} \mathrm{C}\right)$ & $27.24 \pm 0.9$ & $27.39 \pm 0.96$ & $27.43 \pm 0.95$ & $27.33 \pm 0.97$ \\
pH & $7.73 \pm 0.8$ & $8.01 \pm 0.84$ & $7.81 \pm 0.71$ & $7.69 \pm 0.68$ \\
Dissolved oxygen $\left(\mathrm{mg} \mathrm{L}^{-1}\right)$ & $5.75 \pm 1.00^{\mathrm{c}}$ & $7.03 \pm 0.77^{\mathrm{a}}$ & $5.91 \pm 0.85^{\mathrm{c}}$ & $6.57 \pm 0.93^{\mathrm{b}}$ \\
Total ammonia $\left(\mathrm{mg} \mathrm{L}^{-1}\right)$ & $0.20 \pm 0.07$ & $0.15 \pm 0.04$ & $0.17 \pm 0.04$ & $0.17 \pm 0.04$ \\
Nitrite $\left(\mathrm{mg} \mathrm{L}^{-1}\right)$ & $0.02 \pm 0.01$ & $0.01 \pm 0.01$ & $0.02 \pm 0.01$ & $0.01 \pm 0.01$ \\
Alkalinity $\left(\mathrm{mg} \mathrm{L}^{-1}\right)$ & $39.70 \pm 11.97$ & $36.40 \pm 9.74$ & $39.23 \pm 10.76$ & $43.92 \pm 16.05$ \\
Hardness $\left(\mathrm{mg} \mathrm{L}^{-1}\right)$ & $23.31 \pm 11.97^{\mathrm{b}}$ & $28.81 \pm 3.31^{\mathrm{b}}$ & $38.17 \pm 4.12^{\mathrm{a}}$ & $37.84 \pm 4.07^{\mathrm{a}}$ \\
Conductivity $\left(\mu \mathrm{s} \mathrm{cm}^{-1}\right)$ & $139.22 \pm 7.40^{\mathrm{c}}$ & $126.10 \pm 4.57^{\mathrm{b}}$ & $143.64 \pm 7.49^{\mathrm{a}}$ & $143.87 \pm 8.36^{\mathrm{a}}$ \\
\hline
\end{tabular}

Table 3. Growth performance (mean $\pm \mathrm{SD}$ ): survival, length $(\mathrm{cm})$, final weight $(\mathrm{g})$ and weight gain $(\mathrm{g})$. Different superscript letters in a row indicate significant difference $(P<0.05)$.

\begin{tabular}{lcccc}
\hline \multirow{2}{*}{ Parameters } & \multicolumn{4}{c}{ Treatments } \\
\cline { 2 - 5 } & $\mathrm{T} 1$ & $\mathrm{~T} 2$ & $\mathrm{~T} 3$ & $\mathrm{~T} 4$ \\
\hline Survival (\%) & 98 & 89 & 78 & 96 \\
Final length $(\mathrm{cm})$ & $5.87 \pm 0.49^{\mathrm{b}}$ & $4.54 \pm 0.58^{\mathrm{d}}$ & $7.52 \pm 0.53^{\mathrm{a}}$ & $5.38 \pm 0.32^{\mathrm{c}}$ \\
Final weight (g) & $1.61 \pm 0.48^{\mathrm{b}}$ & $0.67 \pm 0.16^{\mathrm{d}}$ & $3.07 \pm 1.18^{\mathrm{a}}$ & $1.09 \pm 1.18^{\mathrm{c}}$ \\
Gain weight (g) & $1.31 \pm 0.48^{\mathrm{b}}$ & $0.37 \pm 0.16^{\mathrm{d}}$ & $2.77 \pm 0.18^{\mathrm{a}}$ & $0.79 \pm 1.18^{\mathrm{c}}$ \\
\hline
\end{tabular}

The survival of prawn was similar in all treatments; however, growth and biomass gain were significantly different. Considering the treatments $\mathrm{T} 1$ and $\mathrm{T} 2$, where the experimental design differed only with feeding supply, the growth was 2.4 times higher in T1 (with feed supply). Among the treatments T3 and T4, the growth was 2.82 times higher in T3 (with feed supply). The growth performance data are presented in Table 3 .

The analysis of isotopic signals (Table 4) revealed that the main source of food in T1 was plankton, with a mean contribution of 46 to $61 \%$. The feed contributed in 24 to $33 \%$ to the growth, and the periphyton and the precipitated organic matter had the lowest contribution intervals.

When analyzing treatment 2 , the contribution of the plankton was close to $20 \%$, while the contribution of the periphyton grows to around $40 \%$, like that found for the precipitated material.

In treatment 3, which contained the greatest diversity of available food sources for prawn, benthic organisms had an average contribution of $28 \%$, and all other sources contributed around $20 \%$. In treatment 4 , the contribution of benthic organisms varied from 27 to $30 \%$, while macrophytes and periphyton were between 20 to $26 \%$ and 29 to $32 \%$, respectively. In the treatments in which macrophytes were available, a contribution between 16 and $32 \%$ was recorded. In the biplot graph for $\delta^{13} \mathrm{C}$ and $\delta^{15} \mathrm{~N}$, it is possible to observe the disposition of the isotopic values of the food sources in relation to the prawn for the different treatments throughout the experiment, represented by groups 1,2 and 3 (Fig. 1a-d).

\section{DISCUSSION}

We observed differences in conductivity, dissolved oxygen and hardness in water quality in the second experiment, probably related to the variation in the communities of microorganisms from different tanks and their relationship with the biological processes of photosynthesis and nitrification (Cesar \& Abreu, 2001). Despite these differences, all parameters remained within the adequate limits to production $M$. amazonicum, as described by Keppeler \& Valenti (2006). However, Sampaio et al. (2007) described the natural occurrence sites of this species, with slight variations in water parameters concerning those observed in our study: temperature $\left(27.5\right.$ to $\left.31^{\circ} \mathrm{C}\right)$, dissolved oxygen (4.6 to $6.1 \mathrm{mg} \mathrm{L}^{-1}$ ) and $\mathrm{pH}$ (7.4 to 8.4).

Timmons et al. (2002) affirmed that the levels of total ammonia and nitrite in warm water aquaculture should be lower than 3 and $1 \mathrm{mg} \mathrm{L}^{-1}$, respectively. The safe levels of total ammonia and nitrite for juveniles of $M$. amazonicum were 2.165 and $0.85 \mathrm{mg} \mathrm{L}^{-1}$ respectively (Dutra et al., 2016c,d). The recommended level 
Table 4. Contribution interval (CI) in percentage to different food sources during the experiment of different food sources contribute to the growth of prawn.

\begin{tabular}{|c|c|c|c|c|c|c|c|c|c|c|}
\hline \multirow{3}{*}{\multicolumn{2}{|c|}{ Treatments food sources }} & \multicolumn{9}{|c|}{ Days } \\
\hline & & \multicolumn{3}{|c|}{ Group $1(\%)$} & \multicolumn{3}{|c|}{ Group $2(\%)$} & \multicolumn{3}{|c|}{ Group $3(\%)$} \\
\hline & & \multicolumn{3}{|c|}{$\overline{\text { Minimum Maximum Mean }}$} & \multicolumn{3}{|c|}{$\overline{\text { Minimum Maximum Mean }}$} & \multirow{2}{*}{$\begin{array}{c}\text { Minimum } \\
0\end{array}$} & \multicolumn{2}{|c|}{ Maximum Mean } \\
\hline \multirow[t]{4}{*}{$\mathrm{T} 1$} & Feed & 2 & 58 & 33 & 1 & 56 & 30 & & 48 & 24 \\
\hline & Periphyton & 0 & 20 & 8 & 0 & 19 & 7 & 0 & 18 & 7 \\
\hline & Plankton & 21 & 78 & 46 & 27 & 79 & 51 & 37 & 87 & 61 \\
\hline & Precipitated & 0 & 37 & 13 & 0 & 32 & 12 & 0 & 25 & 9 \\
\hline \multirow[t]{3}{*}{$\mathrm{T} 2$} & Periphyton & 18 & 65 & 42 & 16 & 66 & 41 & 15 & 63 & 39 \\
\hline & Plankton & 2 & 38 & 21 & 1 & 36 & 19 & 2 & 38 & 21 \\
\hline & Precipitated & 2 & 65 & 37 & 4 & 70 & 40 & 5 & 71 & 40 \\
\hline \multirow[t]{5}{*}{ T3 } & Feed & 0 & 39 & 20 & 0 & 36 & 18 & 0 & 37 & 18 \\
\hline & Periphyton & 1 & 36 & 21 & 0 & 35 & 19 & 0 & 34 & 18 \\
\hline & Plankton & 0 & 28 & 12 & 0 & 34 & 18 & 0 & 34 & 19 \\
\hline & Elodea sp. & 0 & 38 & 19 & 0 & 34 & 16 & 0 & 35 & 17 \\
\hline & Benthic & 2 & 49 & 28 & 1 & 54 & 28 & 1 & 52 & 28 \\
\hline \multirow[t]{4}{*}{$\mathrm{T} 4$} & Periphyton & 2 & 36 & 20 & 8 & 42 & 26 & 9 & 43 & 26 \\
\hline & Plankton & 0 & 28 & 19 & 0 & 36 & 17 & 0 & 33 & 15 \\
\hline & Elodea sp. & 0 & 38 & 31 & 4 & 52 & 29 & 8 & 56 & 32 \\
\hline & Benthic & 0 & 49 & 30 & 0 & 54 & 28 & 0 & 54 & 27 \\
\hline
\end{tabular}

of $\mathrm{CaCO}_{3}$ for $M$. rosenbergii is within the range of 20 to $60 \mathrm{mg} \mathrm{L}^{-1}$ (New, 2002). Thus, the water quality parameters observed in our experiment were adequate for the species.

The isotopic fractionation values were within the range of 0 to $1 \%$ for carbon and 0 to $4 \%$ for nitrogen described by Peterson \& Fry (1987) for aquatic organisms. Yokoyama et al. (2005) reviewed studies with aquatic organisms and found values from -3.7 to $8.7 \%$ for $\delta^{13} \mathrm{C}$ and from -0.7 to $5.8 \%$ or $\delta^{15} \mathrm{~N}$. McCutchan et al. (2003) reviewed the values of isotopic fractionation, which can vary between -2.7 and $3.4 \%$ for $\delta^{13} \mathrm{C}$ and from -0.8 to $5.9 \%$ for $\delta^{15} \mathrm{~N}$, being much more variable than those suggested by Peterson \& Fry (1987). The fractionation could vary among species according to their trophic position (Fry et al., 1999) as well as according to the type and composition of their diet (Ben-David \& Schell, 2001). Also, studies by Post (2002) and Smit (2001), both in the laboratory and in natural environments, indicate that isotopic carbon fractionation is not constant and depends on the nutritional quality of the diet.

In order to explain the possible relationship between isotopic fractionation and food quality, Fantle et al. (1999) created a conceptual model where fast-growing crabs fed on energy-rich sources, active metabolites, and amino acids for biosynthesis of new tissues. Because it is a carbon-rich diet, the carbon is incorporated into the new synthesized tissue and $\delta^{13} \mathrm{C}$ resembles that of the food ingested. However, the slow growth induced by a low-protein diet would cause a greater carbon fractionation and a value of $\delta^{13} \mathrm{C}$ that is heavier than the diet, since the low-quality food source leads to the catabolism of proteins and lipids from the tissue reserves of the animals. Before estimating the food intake of potential food sources, it is necessary to quantify the isotopic fractionation that occurs during the uptake of the food by the consuming organism, since erroneous estimates of isotopic fractionation may lead to erroneous conclusions about the possible sources of food that an organism uses (McCutchan et al., 2003). Thus, the results of experiment 1 confer greater reliability to the estimates of food source contribution in experiment 2. Also, the data on the growth performance of the prawn also reinforce the importance of food availability for their biomass gain, which was limited due to restricted access to the feed.

In our study, the final length and weight gain best results occurred in the treatment with substrate, macrophytes and feed supply, and the worst performance occurred in the treatment without feed and substrate. Kimpara et al. (2011) produced $M$. amazonicum that reached $3.80 \pm 0.16 \mathrm{~g}$ after 3.5 months, which was like our treatment $\mathrm{T} 3$ with the addition of feed and access to natural sources. Our results from treatment $\mathrm{T} 1$ were like those observed by Dutra et al. (2016a) with M. amazonicum produced in different densities but similar conditions (final weight $=1.86 \pm 0.28$ to $2.50 \pm 0.09 \mathrm{~g}$; length $=5.03 \pm 2.19$ to $6.73 \pm 0.90 \mathrm{~cm})$. Dutra et al. (2016b) produced the same species in ponds, and obtained final weight and length of $4.83 \pm 1.03 \mathrm{~g}$ and $8.42 \pm 0.51 \mathrm{~cm}$ respectively, with 

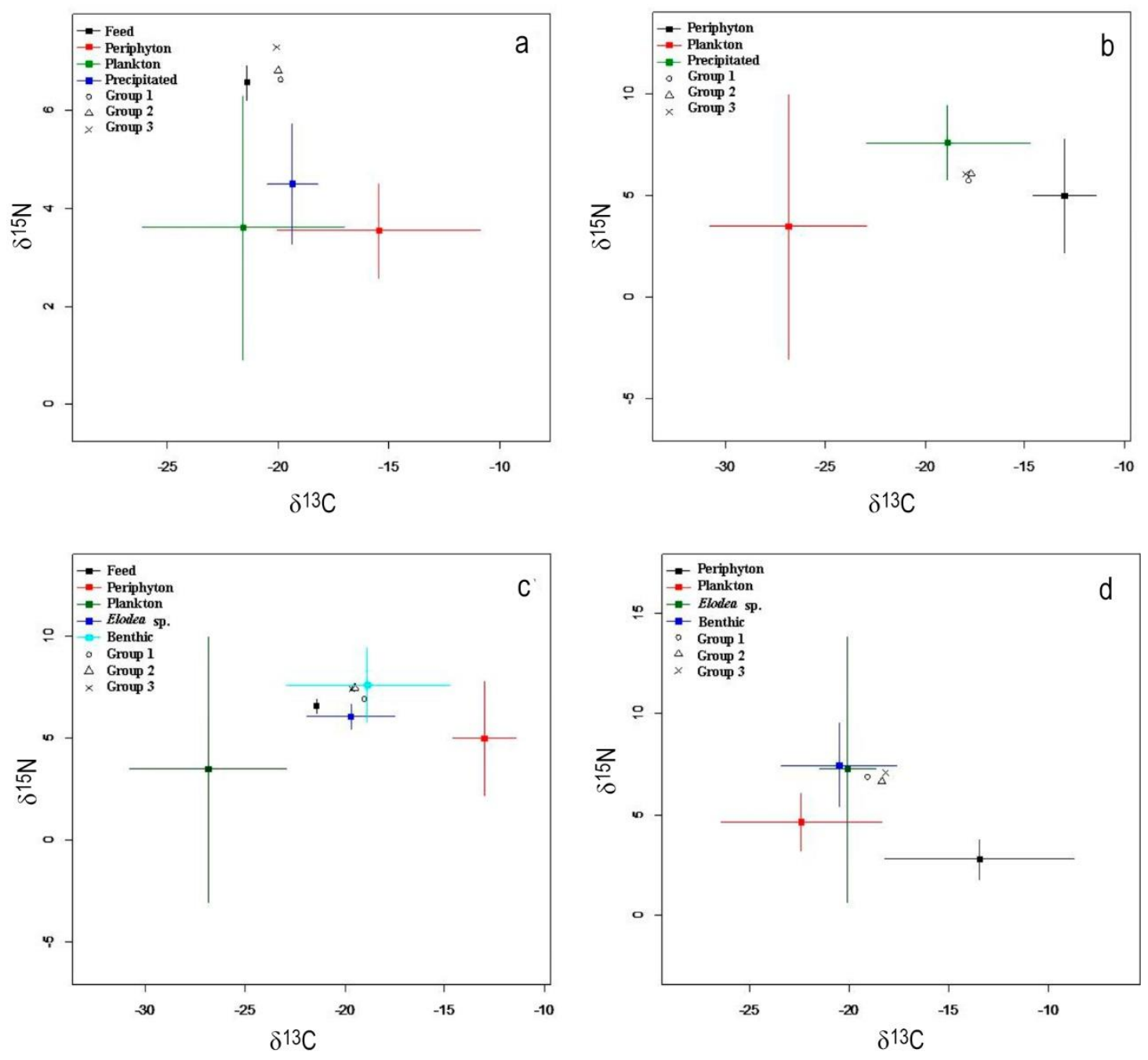

Figure 1. Biplot graph with the isotopic values of $\mathrm{C}$ and $\mathrm{N}$ in the different food sources and prawn tissues for the different treatments: a) T1, b) T2, c) T3 and d) T4, and Group 1 (day 20), Group 2 (day 40) and Group 3 (day 60).

feed supply and $4.43 \pm 0,93 \mathrm{~g}$ and $8.03 \pm 0.43 \mathrm{~cm}$ without feed, with no statistical differences between treatments. Our experiment was carried out in isolated tanks, without the continuous recruitment of natural food sources, which could be the explanation for the difference between these two studies. The effect of the recruitment of natural food sources was also confirmed by Soares et al. (2004) produced marine shrimps in ponds installed within the Patos Lagoon Estuary (RS, Brazil).

The survival of prawns during the study was higher than the values from 40 to $60 \%$ reported by Wichins \& Lee (2002) with the genus Macrobrachium in semiintensive crops in excavated ponds. However, our results were similar to those found by Souza et al. (2009) in a polyculture of $M$. amazonicum and Oreochromis niloticus, ranging from 71.5 to $77 \%$.
Preto et al. (2008) tested the feeding trays for $M$. amazonicum and recorded an average survival of 85.8\%. Moraes-Valenti \& Valenti (2007) observed survivals above $60 \%$ for $M$. amazonicum grown for five and a half months at densities of 10 and 80 ind $\mathrm{m}^{-2}$, with a mean weight of 7.0 and $3.6 \mathrm{~g}$, respectively. The lowest survival in our study occurred in the treatment T3, where the prawn achieved greater growth and weight gain. These values are also probably related to the higher biomass of prawn per unit area, a fact that has already been reported in other studies with this species (Moraes-Valenti \& Valenti, 2007; Dutra et al., 2016a). Thus, we can affirm that the survival range in our study corroborates previously registered data.

In general, we can affirm that the differences in the availability of food sources directly influenced the growth performance of prawn. The growth in size and 
biomass of the prawns was higher in treatment $\mathrm{T} 1$. The feed contributed least to the growth performance but still enhanced it, either by direct consumption or by the stimulus that leftovers feed remains may have generated to the development and nutritional improvement of the natural food sources present in the environment. Prawn can absorb about 18 to $30 \%$ of the food ingested (Funge-Smith \& Stewart, 1996), the remainder being a good source of carbon and nitrogen for primary producers.

Previous studies demonstrate the importance of periphyton for shrimp growth, including postlarvae (Buford et al., 2004; Abreu et al., 2007; Ballester et al., 2018). The benthic organisms contributed the most in treatment T3, which also contained the greatest diversity of food sources available to the prawn. The contribution of benthic organisms remained practically unchanged, whereas macrophytes and periphyton grew in importance for the development of prawn in the treatment $\mathrm{T} 4$, which had the same food sources of $\mathrm{T} 3$ except for the feed. Ballester et al. (2016) determined a higher contribution (37 to 54\%) of benthic organisms to the marine shrimp $F$. paulensis, which was higher than in our study, though the shrimp were produced in ponds located in an estuarine area, allowing the recruitment of benthic organisms and greater biomass gain. In that work, authors also observed that, as in our study, the microbial communities from the periphyton and shallow sediments contributed more in the treatment without a feed (50\%) than in the treatment with feed supply (22.6\%).

Soares et al. (2008) fed $F$. paulensis with various aquatic plants observed in their stomach contents and observed that their growth was almost nil, only being associated with the periphyton growing on the plants. Ballester et al. (2016) evaluated the dietary sources for $F$. paulensis using the stable isotope technique and found low contributions from plant material, evidencing the low capacity of this species in digesting cellulose. However, Padovani (1992) analyzed three freshwater prawn species in lowland lakes in central Amazonia and observed that $85.3 \%$ of their carbon came from plants.

In our study, macrophytes had an important contribution to the shrimp growth, which corroborates the results found by Rocha (2016), who identified enzymes like cellulases, especially endo-beta-mannanase and beta-endoglucanase, in the hepatopancreas of $M$. amazonicum. This species presents cellulose digestion capacity, evidenced by its feeding habits and the frequent presence of plant fibers in their stomach contents (Kensley \& Walker, 1982; Melo \& Nakasaki, 2013; Aguiar, 2016). Besides, Rocha (2016) also identified other classes of enzymes such as amylases, proteases, and chitinases, demonstrating the ability of these shrimp to take advantage of several food sources. The availability of proteins and amino acids present in the diet leads to an enrichment of food sources with the addition of carbon and nitrogen in the system (Fantle et al., 1999). We observed a much higher biomass gain in the treatment T1 (with feed supply) compared to T4 since it supplied the nutrients required by the species.

Our results on the availability and contribution of different food sources to the biomass gain reinforce previous knowledge on the omnivory of prawn and their plasticity in the use of food sources. It is worth mentioning the contribution of feed and benthic organisms that was fundamental for the better growth performance of juvenile of $M$. amazonicum under experimental conditions, either by direct consumption or by the enrichment of other available food sources. On the other hand, the contribution of the plankton, periphyton, and precipitated material were higher in the treatments where benthic organisms and feed were not available.

Estimating the effective contributions of food sources can help in developing diets more adequate for the species, increasing productivity, reducing costs and reducing the environmental impact of waste substances.

\section{REFERENCES}

Abreu, P.C., Ballester, E.L.C., Odebrecht, C., Wasielesky, W., Cavalli, R.O., Wilhelm, G. \& Anesio, A. 2007. Importance of biofilm as a food source for shrimp (Farfantepenaeus paulensis) evaluated by stable isotopes $(\delta 13 \mathrm{C}$ and $\delta 15 \mathrm{~N})$. Journal of Experimental Marine Biology and Ecology, 347: 88-96.

Aguiar, F.P. 2016. Dinâmica populacional e hábitos alimentares de Macrobrachium sob a influência de barragens. Mestrado em Ecologia Aplicada, Universidade Federal de Lavras, Lavras, 122 pp.

Ballester, E.L.C., Wasielesky Jr. W., Cavalli, R.O., Ducatti, C. \& Abreu, P.C. 2016. Avaliação das fontes alimentares utilizadas pelo camarão rosa Farfantepenaeus paulensis a través de isótopos estáveis $(\delta 13 \mathrm{C}$ and $\delta 15 \mathrm{~N})$. In: Wasielesky Jr., W. \& Poersch, L.H. (Eds.). Cultivo de camarões em gaiolas e cercados no estuário da Lagoa dos Patos. Editora da FURG, Rio Grande, pp. 302-324.

Ballester, E.L.C., Dutra, F.M., Pisseti, T.L., Cavalli, R.O., Abreu, P.C. \& Wasielesky, W. 2018. Influence of biofilm on the production of Farfantepenaeus paulensis in pens in the Patos Lagoon estuary. Aquaculture International, 26(3): 713-726.

Ben-David, M. \& Schell, D.M. 2001. Mixing models in analyses of diet using multiple stable isotopes: a response. Oecologia, 127:180-184. 
Buford, M.A., Melony, J.S., Stuart, J.A., Sandy, J.K., Peter, J.C. \& Nigel, P.P. 2004. Contribution of the natural biota associated with substrates to the nutritional requirements of the post-larval shrimp, Penaeus esculentus (Haswell), in high-density rearing systems. Aquaculture Research, 35: 508-515.

Cardona, E., Lorgeoux, B., Geffroy, C., Richard, P., Saulnier, D., Gueguen, Y., Guillou, G. \& Chim, L. 2015. Relative contribution of natural productivity and compound feed to tissue growth in blue shrimp (Litopenaeus stylirostris) reared in biofloc: assessment by $\mathrm{C}$ and $\mathrm{N}$ stable isotope ratios and effect on key digestive enzymes. Aquaculture, 448: 288-297.

Cesar, D.E. \& Abreu, P.C. 2001. Ecology of aquatic microorganisms in Southen Brazil. State of art. In: Faria, B.M. \& Farjall, V.F. (Eds.). Aquatic microbial ecology in Brazil. Series Oecologia Brasiliensis, PPGE-UFRJ, Rio de Janeiro, pp. 153-172.

Coman, F.E., Connolly, R.M., Bunn, S.E. \& Preston, N.P. 2006. Food sources of the sergestid crustacean, Acetes sibogae, in shrimp ponds. Aquaculture, 259: 222-233.

Cutolo, M.A. \& Valenti, W.C. 2005. Manejo alimentar de pós-larvas do camarão-da-amazônia, Macrobrachium amazonicum, em berçário I. Acta Scientiarum. Animal Science, 27(1): 67-72.

Dutra, F.M., Borges-Neto, P.G., Forneck, S.C. \& Ballester, E.L.C. 2016a. Desempenho zootécnico de juvenis de Macrobrachium amazonicum sob diferentes densidades de estocagem em sistema de recirculação. Brazilian Journal of Fisheries Engineering, 9: 27-36.

Dutra, F.M., Moretto, Y., Portz, L. \& Ballester, E.L.C. 2016b. Pen culture of Macrobrachium amazonicum: use of artificial diet and impact of benthic community. Aquaculture Research, 47: 266-275.

Dutra, F.M., Forneck, S.C., Brazão, C.C., Freire, C.A. \& Ballester, E.L.C. 2016c. Acute toxicity of ammonia to various life stages of the Amazon river prawn, Macrobrachium amazonicum, Heller, 1862. Aquaculture, 453: 104-109.

Dutra, F.M., Freire, C.A., Santos, A.M.V., Forneck, S.C., Brazão, C.C. \& Ballester, E.L.C. 2016d. Acute toxicity of nitrite to various life stages of the Amazon river prawn, Macrobrachium amazonicum, Heller, 1862. Bulletin of Environmental Contamination Toxicology, 97(5): 619-625.

Food and Agriculture Organization (FAO). 2016. Fishstat plus-aquaculture production: quantities 1950-2010. [http://www.fao.org/fishery/statistics/software/fishstat /en]. Reviewed: 1 November 2016.

Fantle, M.S., Dittel, A.I., Schwalm, S.M., Epifranio, C.E. \& Fogel, M.L. 1999. A food web analysis of the juvenile blue crab, Callinectes sapidus, using stable isotopes in whole animals and individual amino acids. Oecologia, 120: 416-426.
Fry, B. 2003. Steady-state models of stable isotopic distribution. Isotopes in Environmental and Health Studies, 39: 219-232.

Fry, B. 2006. Stable isotope ecology. Springer, New York.

Fry, B., Mundford, P.L., Tam, F., Fox, D.D., Warren, G.L., Havens, K.E. \& Steinman, A.D. 1999. Trophic position and individual feeding histories of fish from Lake Okeechobee, Florida. Canadian Journal of Fisheries and Aquatic Science, 56: 590-600.

Funge-Smith, S. \& Stewart, J. 1996. Coastal aquaculture: identification of social, economic and environmental constraints to sustainability with reference to shrimp culture. Proj. Tech. Rep. University of Stirling, 30 pp.

Gamboa-Delgado, J. \& Le Vay, L. 2009. Nitrogen stable isotopes as indicators of the relative contribution of soy protein and fish meal to tissue growth in Pacific white shrimp (Litopenaeus vannamei) fed compound diets. Aquaculture, 291: 115-123.

Gamboa-Delgado, J., Rojas-Casas, M.G., Nieto-López, M.G. \& Cruz-Suárez, L.E. 2013. Simultaneous estimation of the nutritional contribution of fish meal, soy protein isolate and corn gluten to the growth of Pacific white shrimp (Litopenaeus vannamei) using dual stable isotope analysis. Aquaculture, 380-383: 33-40.

Groot, P.A. 2004. Handbook of stable isotope analytical techniques. Elsevier, Amsterdam.

Junger, H., Kotrschor, K. \& Goldschmidt, A. 1988. Situs, relative length and mucosal surface structure of the gut in European cyprinids (Teleostei, Cyprinidae). Oesterr Fish, 41(5-6): 1-102.

Kensley, B. \& Walker, I. 1982. Palaemonid shrimps from the Amazon Basin, Brazil (Crustacea: Decapoda: Natantia). Smithsonian Contributions to Zoology, 362: $1-27$.

Keppeler, E.C. \& Valenti, W.C. 2006. Effects of selective harvest of the Amazon river prawn, Macrobrachium amazonicum, on pond water, sediment and effluent. Acta Limnologica Brasiliensia, 18: 109-119.

Kimpara, J.M., Rosa, F.R.T., Preto, B.L. \& Valenti, W.C. 2011. Limnology of Macrobrachium amazonicum grow-out ponds subject to high inflow of nutrient-rich water and different stocking and harvest management. Aquaculture Research, 42(9): 1289-1297.

Mackereth, F.J.H., Heron, J. \& Talling, J.F. 1978. Water analysis: some revised methods for limnologists. Freshwater Biological Association, Cumbria.

Marques, H.L.A. \& Moraes-Valenti, P.M.C. 2012. Current status and prospects of farming the giant river prawn (Macrobrachium rosenbergii (De Man 1879) and the Amazon river prawn Macrobrachium amazonicum 
(Heller 1862)) in Brazil. Aquaculture Research, 43: 984-992.

McCutchan, J.H., Lewis, W.M., Kendall, C. \& McGrath, C.C. 2003. Variation in trophic shift for stable isotope ratios of carbon, nitrogen, and sulfur. Oikos, 102(2): 378-390.

Melo, M.S. \& Nakagaki, J.M. 2013. Evaluation of the feeding habits of Macrobrachium brasiliense (Heller, 1862) in the Curral de Arame stream (Dourados/Mato Grosso Do Sul, Brazil). Nauplius, 21(1): 25-33.

Maciel, C.R. \& Valenti, W.C. 2009. Biology, fisheries, and aquaculture of the Amazon river prawn Macrobrachium amazonicum: a review. Nauplius, 17(2): 61-79.

Moraes-Valenti, P.M.C. \& Valenti, W.C. 2007. Effect of intensification on growth out of the Amazon river prawn, Macrobrachium amazonicum. Journal of the World Aquaculture Society, 38(4): 516-526.

Moraes-Valenti, P.M.C. \& Valenti, W.C. 2010. Culture of the Amazon river prawn Macrobrachium amazonicum. In: New, M.B., Valenti, W.C., Tidwell, J.H., D'Abramo, L.R. \& Kutty, M.N. (Eds). Freshwater prawns; biology and farming. Wiley-Blackwell, Oxford, pp. 485-501.

Moretti, V.M., Turchini, G.M., Bellagamba, F. \& Caprino, F. 2003. Traceability issues in fishery and aquaculture products. Veterinary Research Communications, 27(1): 497-505.

New, M.B. 2002. Farming freshwater prawns. A manual for the culture of the giant river prawn (Macrobrachium rosenbergii). FAO Fisheries Technical Paper, 428: 212 pp.

New, M.B., D'Abramo, L.R., Valentim W.C. \& Singholka, S. 2010. Sustainability of freshwater prawn culture. In: New, M.B., Valenti, W.C., Tidwell, J.H., D'Abramo, L.R. \& Kutty, M.N. (Eds.). Freshwater prawns: biology and farming. Wiley-Blackwell, Oxford, pp. 524-530.

Ostrensky, A. \& Boeger, W. 1998. Piscicultura: fundamentos e técnicas de manejo. Livraria e Editora Agropecuária, Guaíba.

Padovani, C.R., 1992. Determinação das fontes autotróficas de carbono para camarões em um lago de várzea da Amazônia central utilizando isótopos estáveis de carbono. Mestrado em Biologia, Instituto Nacional de Pesquisas da Amazônia/Universidade Federal do Amazonas, Manaus, 72 pp.

Parnell, A.C., Inger, R., Besrhop, S. \& Jackson, A.L. 2010. Source partitioning using stable isotopes: coping with too much variation. Plos One 5(3): e9672.

Penteado, J.M.A., Proenand, D.C. \& Valenti, W.C. 2013. Analysis of productivity of Amazon river prawn, Macrobrachium amazonicum, in four nursery systems. World Aquaculture Society Meetings. [https://www.
was.org/meetings/ShowAbstract.aspx?Id=29220]. Reviewed: 1 February 2017.

Peterson, B.J. \& Fry, B. 1987. Stable isotopes in ecosystem studies. Annual Review of Ecological Systems, 18: 293-320.

Phillips, D.L. \& Gregg, J.W. 2003. Source partitioning using stable isotopes: coping with too many sources. Oecologia, 136: 261-269.

Post, D.M. 2002. Using stable isotopes to estimate trophic position: models, methods, and assumptions. Ecology, 83: 703-718.

Preto, B.L., Pizzato, G.M. \& Valenti, W.C. 2008. Uso de bandejas de alimentação na fase de engorda do camarão-da-amazânia, Macrobrachium amazonicum (Heller, 1862). Boletim do Instituto de Pesca, 34(1): 125-130.

Rocha, C.P. 2016. Prospecção de genes putativos para enzimas digestivas a partir de uma biblioteca de cDNA do hepatopâncreas de Macrobrachium amazonicum (Heller, 1862). Mestrado em Biologia Ambiental, Universidade Federal do Pará, Bragança, 86 pp.

Sampaio, C.M.S., Silva, R.R., Santos, J.A. \& Sales, S.P. 2007. Reproductive cycle of Macrobrachium amazonicum females (Crustacea, Palaemonidae). Brazilian Journal of Biology, 67: 551-559.

Smit, A.J. 2001. Source identification in marine ecosystems. In: Unkovich, M., Pate, J., McNeill, A. \& Gibbs, D.J. (Eds.). Stable isotope techniques in the study of biological processes and functioning of ecosystems. Current plant science and biotechnology in agriculture. Springer, Dordrecht, pp. 219-245.

Sokal, R.R. \& Rohlf, F.J. 2012. Biometry: principle and practices of statistics in biological research. W.H. Freeman \& Company, New York, 880 pp.

Soares, R., Peixoto, S., Wasielesky, W. \& D'Incao, F. 2008. Effects of feeding plant material on growth and survival of pink shrimp Farfantepenaeus paulensis, Atlântica, Rio Grande, 30(1): 17-22.

Soares, R., Peixoto, S., Benvenuti, C., Wasielesky, W., D'Incao, F., Murcia, N. \& Suita, S.M. 2004. Composition and abundance of invertebrate benthic fauna in Farfantepenaeus paulensis culture pens (Patos Lagoon Estuary, Southern Brazil). Aquaculture, 239: 199-215.

Souza, B.E., Stringuetta, L.L., Bordignon, A.C., Bohnenberger, L., Boscolo, W.R. \& Feiden, A. 2009. Policultivo do camarão de água doce Macrobrachium amazonicum (Heller, 1862) com tilápia do Nilo (Oreochromis niloticus) alimentadas com rações peletizadas e fareladas. Ciências Agrárias, 30(1): 225232. 
Suita, S.M., Braga, A., Ballester, E.L.C., Cardoso, A.P., Abreu, P.C. \& Wasielesky, W. 2016. Contribution of bioflocs to the culture of Litopeneaus vannamei postlarvae determined using stable isotope. Aquaculture International, 24(5): 1473-1487.

Timmons, M.B., Ebeling, J.M., Weathon, F.W., Summerfelts, S.T. \& Vinci, B.J. 2002. Recirculating aquaculture system. Cayuga Aqua Ventures, Ithaca.

Valenti, W.C. 2007. Current status of freshwater prawn culture in Brazil. In: Nair, C.M., Nambudiri, D.D., Jose, S., Sankaran, T.M., Jayachandran, K.V. \& Salin, K.R. (Eds.). Freshwater prawns: advances in biology, aquaculture \& marketing. Allied Publishers, New Delhi, pp. 105-110.

Received: 12 May 2017; Accepted: 22 November 2018
Walker, R. 1978. Water supply, treatment, and distribution. Prentice-Hall, New Jersey.

Wickins, J.F. \& Lee, D.O. 2002. Crustacean farming: ranching and culture. Blackwell Science, Oxford.

Yokoyama, H., Tamaki, A., Harada, K., Shimoda, K., Koyama, K. \& Ishihi, Y. 2005. Variability of diettissue isotopic fractionation in estuarine macrobenthos. Marine Ecology Progress Series, 296: 115128.

Zavala-Camin, L.A. 1986. Introdução aos estudos sobre alimentação natural em peixes. Eduem Nupelia, Maringá. 